\title{
Physical exercise and blood flow properties
}

\author{
G. Ciuffetti, MD, M. Mercuri, MD, R. Lombardini, MSc, U. Milia, MD, E. Mannarino, MD
}

Second Department of Internal Medicine, University of Perugia, Italy

\begin{abstract}
In 46 executive level managers at risk for cardiovascular disease, whole blood filterability through five micron pore Nuclepore filters was monitored using a constant flow positive pressure system before and after treadmill exercise and compared to our laboratory standard. Our results show regular exercise compensates not only for the potential damage risk factors represent but also for the physical stress provoked by vigorous exercise.
\end{abstract}

Keywords: Cardiovascular risk factors, exercise, blood filterability

\section{Introduction}

Blood rheology is abnormal in the presence of all cardiovascular risk factors ${ }^{1}$. The benefits of regular physical exercise in the prevention of ischaemic syndromes have often been expounded ${ }^{2-5}$. Since whole blood filterability (WBF) is generally considered the expression of capillary blood flow ${ }^{6}$ and tissue perfusion, ${ }^{7}$ we investigated its behaviour before and after physical stress. This was provoked by vigorous treadmill exercise in a group of 46 middle-aged male executive level managers. All belonged to the social group most at risk for cardiovascular disease.

\section{Materials and methods}

Forty-six male smokers aged between 40 and 55 years of age (average age $47 \pm 4$ years s.d.), with no clinical sign or symptom of cardiovascular disease were recruited to the study. All were clinically healthy and did not take medication of any sort.

Cardiovascular risk factors present in the group were as follows: 14 had borderline high blood pressure (145-150 mmHg/95-100 $\mathrm{mmHg}$ ); nine had hyperlipoproteinaemia ( $<240 \mathrm{mg} \%$ cholesterol; $<200 \mathrm{mg} \%$ tryglycerides); 15 were overweight (Broca index exceeding ten per cent); nine had reduced responses to glycaemic stimulus (pre-diabetes) and 25 were under psycho-social stress. Numbers total more than 46 because some patients had more than one risk factor.

All patients gave their informed consent to the study which was approved by the hospital ethics committee.

Address for correspondence: Dr Giovanni Ciuffetti, 2a Clinica Medica, Universita' degli Studi di Perugia, Policlinico Monteluce, 06100 Perugia, Italy
On the basis of answers to questions on their life style in the previous three years, subjects were divided into three groups (Table 1):

Sedentary No regular fitness programme

Out-of-condition Exercising irregularly once or twice a week

Fit Exercising regularly three times a week.

Blood samples were drawn immediately before and after vigorous exercise on a treadmill $(4 \mathrm{~km} /$ hour; 15 per cent slope). A 12 lead electrocardiogram (Minocard 3, Siemens Elema, WG) was recorded during exercise and leads II, V2 and V5 were displayed and monitored continuously. Blood pressure was measured in the right arm by sphygomanometry every two minutes. Exercise test end points were:

The target heart rate ( 85 per cent of the maximum heart rate predicted on the basis of age)

A minimum of six minutes exercise

Development of $>=1 \mathrm{~mm}$ planar downsloping ST segment depression $80 \mathrm{~ms}$ after the J point in three consecutive complexes, compared to rest electrocardiogram.

Five of the sedentary subjects were dropped from the study because of complications including leg cramps (three), dizziness (one), and near syncope (one). Exercise times for the remaining 41 subjects varied from six to 15 minutes (Table 1).

Table 1. Main clinical details and treadmill exercise of 46 smokers divided into three groups: sedentary, out-ofcondition and fit. Values are means (standard deviation in brackets)

\begin{tabular}{lccr}
\hline & & Out-of- \\
& Sedentary & condition & Fit \\
\hline Number & 16 & 14 & 11 \\
Age (yr) & $47(4)$ & $48(4)$ & $47(4)$ \\
Height (cm) & $178(5)$ & $176(4)$ & $177(4)$ \\
Weight (kg) & $82(5)$ & $79(4)$ & $80(4)$ \\
Cardiovascular risk factors & 16 & 14 & 11 \\
$\quad$ Smoking & 6 & 5 & 3 \\
$\quad$ Borderline hypertension & 4 & 3 & 2 \\
$\quad$ Hyperlipoproteinemia & 6 & 5 & 4 \\
Overweight & 4 & 8 & 7 \\
$\quad$ Pre-diabetes & 10 & & \\
$\quad$ Psycho-social stress & & $465(62)$ & 900 \\
Treadmill test & & & \\
$\quad$ Exercise time (sec) & $430(47)$ & & \\
\hline
\end{tabular}

Age, height, weight and exercise time are average values (standard deviation in brackets) 
Whole blood was prepared for filtration by suspending it at 10 per cent haematocrit in two per cent phosphate buffered saline ( $\mathrm{pH} \mathrm{7.4,} \mathrm{osmolality}$ $290 \mathrm{mmol} / \mathrm{kg}$ ) (Dulbecco, Uxoid Ltd, UK). The filtration methodology has been described in detail elsewhere. ${ }^{8}$ Reliability was good. After filtration no significant differences in the percentage of 'active' cells as defined by Nash et al. ${ }^{9}$ were found in the whole blood suspensions.

The subjects' filterability rates before exercise were compared both to our laboratory standard of 150 healthy volunteers, and to those obtained after exercise.

\section{Results}

Table 2 summarizes our results. Before exercise, the average WBF rate in the total group of managers was significantly ( $\mathrm{p}<0.001$ ) higher (mean confidence $0.58 ; 95$ per cent confidence interval from 0.31 to 0.85 ) than our normal laboratory standard. After division into the three sub-groups the values of the sedentary and out-of-condition groups remained significantly ( $p<0.001$ ) higher $(0.90 ; 95$ per cent 0.46 to $1.35 ; 0.66$; 0.19 to 1.12 ) but those of the fit group fell within the normal range.

After exercise the WBF rate increased significantly $(p<0.001)$ in the sedentary group $(1.21 ; 0.96$ to 1.69$)$ and in the out-of-condition group $(1.01 ; 0.43$ to 1.59$)$ compared not only to their values before exercise but

Table 2. Whole blood filterability (WBF) rates* in executive level managers before and after vigorous treadmill exercise. Values are means (standard deviation in brackets)

\begin{tabular}{|c|c|c|}
\hline $\begin{array}{l}\text { Laboratory standard** } \\
\qquad 95 \% \mathrm{Cl}\end{array}$ & $\begin{array}{l}6.14(0.87) \\
6.00-6.28\end{array}$ & \\
\hline Managers & Before & After \\
\hline $\begin{array}{l}\text { Total group (No. 46) } \\
95 \% \mathrm{Cl}\end{array}$ & $\begin{array}{l}6.72(0.57) a \\
6.55-6.89\end{array}$ & \\
\hline $\begin{array}{l}\text { Sedentary (No. 16) } \\
\quad 95 \% \mathrm{Cl}\end{array}$ & $\begin{array}{l}7.04(0.61) \mathrm{a} \\
6.72-7.37\end{array}$ & $\begin{array}{l}8.25(0.62) \#() \\
7.92-8.58\end{array}$ \\
\hline $\begin{array}{l}\text { Out-of-condition (No. 14) } \\
95 \% \mathrm{Cl}\end{array}$ & $\begin{array}{l}6.80(0.41) a \\
6.56-7.03\end{array}$ & $\begin{array}{l}7.46(0.84) \#(C) \\
7.24-8.37\end{array}$ \\
\hline $\begin{array}{l}\text { Fit (No. 11) } \\
\qquad 95 \% \mathrm{Cl}\end{array}$ & $\begin{array}{l}6.18(0.34) \\
5.96-6.41\end{array}$ & $\begin{array}{l}6.13(0.66) \\
5.68-6.57\end{array}$ \\
\hline \multicolumn{3}{|c|}{$\begin{array}{l}\text { * Pressure ratio of cell suspension to buffer after six minutes } \\
\text { filtration } \\
\text { ** Based on average values of } 150 \text { normal healthy volunteers } \\
\mathrm{Cl} \text { Confidence Interval } \\
\text { a } p<0.001 \text { vs laboratory standard (unpaired Wilcoxon Test) } \\
\text { C } p<0.001 \text { vs fit group (unpaired Wilcoxon Test) } \\
\# p<0.001 \text { vs values before exercise (t Test) }\end{array}$} \\
\hline
\end{tabular}

also to those of the fit group after exercise $(2.12 ; 1.61$ to 2.64 for sedentary and $1.68 ; 0.90$ to 2.08 for out-of-condition).

\section{Discussion}

Our results show that significant abnormalities in whole blood filterability accompany the known risk factors for cardiovascular disease. However, these abnormalities are greatly attenuated in subjects who exercise regularly at least three times a week.

A brief period of vigorous exercise greatly increased the impairment in whole blood filterability rates only in subjects who did not exercise regularly. This shows the value of regular exercise in compensating not only for physical stress but also for the potential damage caused by the presence of cardiovascular risk factors.

The final point to emerge from this study is that exercise must be undertaken regularly to avail of these compensatory benefits. In fact, no significant differences emerged in the filterability rates of the sedentary group and those who only exercised occasionally.

\section{Acknowledgements}

The authors wish to thank Mrs G.A. Boyd Mancinelli and $\mathrm{Mr}$ Christian Ott for their invaluable assistance in preparation of this manuscript.

\section{References}

1 Ernst, E., Weihmayr, T., Schmid, M., Baumann, M. and Matrai, A. S'rdiovascular risk factors and hemorheology Atherosclerosis 1986, 59, 263-269

2 Letcher, R.L., Pickering, T.G., Chien, S. and Laragh, $H$. Effects of exercises on plasma viscosity in athletes and sedentary normal subjects Clin Cardiol 1981, 4, 172

3 Ernst, E., Matrai, A. and Aschenbrenner, E. Blood rheology in athletes J Sport Med Phys Fitness 1985, 4, 207-10

4 Ernst, E. Changes in blood rheology produced by exercise JAMA 1985, 253, 2962

5 Ernst, E., Matrai, A., Siepmanmn, P. and Schmid, A. Blood rheology of former and active athletes $J$ Sports Med 1987, 27, 373-5

6 Lowe, G.D.O. Blood rheology in arterial disease Clin Sci 1986, 71, 137-46

7 Lowe, G.D.O. Blood rheology in vitro and in vivo Bailliere's Clin Haematol 1987, 597-636

8 Lennie, S.E., Lowe, G.D.U., Berbenel, J.C., Forbes, C.D. and Foulds, W.S. Filterability of white blood cell subpopulations, separated by an improved method Clin Hemorheol 1987, 7, 811-6

9 Nash, G.B., Jones, J. G., Mikita, J., Christopher, B. and Dormandy, J.A. Effects of preparative procedures and of cell activation on flow of white cells through micropore filters Br J Haematol 1988, 70, 171-6 